http://journals.ums.ac.id/index.php/ijolae

\title{
Design of Mathematics Learning Media based on Discovery Learning to Improve Problem Solving Ability
}

Epa Wira Darmawan', Suparman²

1,2 Master of Mathematics Education, University of Ahmad Dahlan, Indonesia

DOI: 10.23917/ijolae.v1i2.7564

Accepted: January 14th, 2019 Approved: May 6th, 2019. Published: July 1st, 2019

\begin{abstract}
Problem-solving is one of the $21^{\text {st }}$ century skills and is included in the 2013 curriculum. Students with low problem-solving abilities will have difficulty completing math problems that require high-level thinking. Learning media that does not contain problem-solving skills will hinder the achievement of student competence. This research has two objectives. The first objective is to analyze the needs of learning media that are in accordance with student characteristics, curriculum, learning models and teacher readiness. The second objective is to design discovery learning based learning media to improve students' problem-solving abilities. This research uses design research method with type of development studies. The research subjects consisted of teachers and students. Data collection instruments used interview guidelines, observation guidelines, and questionnaires. Interview guides to get information from teachers and students regarding the readiness of teachers in applying the 2013 curriculum and learning difficulties in mathematics. Observation guidelines are used to obtain information about student learning characteristics. The questionnaire was used to get the needs of mathematics learning media. The data were analyzed using qualitative descriptive. Research provides several results. First, most students consider learning less attractive. Second, the 2013 curriculum cannot be fully implemented in the classroom. Third, discovery learning models can improve problem-solving skills. Fourth, the design of discovery learning based learning media. This study concludes that discovery learning based media to improve problem-solving skills needs to be developed
\end{abstract}

Keywords: media development, guide discovery model, troubleshooting.

Corresponding Author:

Epa Wira Darmawan, Master of Mathematics Education, University of Ahmad Dahlan, Indonesia e-mail : epawiradarmawan@gmail.com

\section{Introduction}

Problem-solving is the process used in solving problems. Mayer (in Kirkley, 2003) defines problem-solving as a stage of the process of finding a relationship between experience and the problem at hand and then acting with the solution found. According to Polya (1973) Problem solving is an attempt to find a way out of a difficulty in achieving a goal that is not immediately achievable.

Problem-solving is a focus in learning mathematics which includes closed problems with a single solution, open problems with no single solutions, and problems with various ways of completion (Santosa, Prabawanto, \& Marethi, 2019)

Problem-solving is one of the abilities that students must master after learning mathematics (National Council of Teachers of Mathematics, 2000). This ability is needed by students and related to the needs of students to solve the problems in their daily lives and develop themselves (Mulyati, 2016).

The ability to solve problems is important. Research results show problemsolving strategies in learning mathematics, for certain things can be applied in other problem-solving situations (Bell, 1978). 
Ruseffendi (2006) suggests that problem-solving abilities are very important in mathematics, not only for those who will later study mathematics, but also for those who will apply them in other fields of study and in everyday life. Problem-solving ability is the heart of mathematics (Branca, 1980).

However, the reality in the field is not yet in accordance with what is expected, mathematics learning still tends to orient to textbooks. It is not uncommon to find mathematics teachers who are still attached to their teaching habits by using learning steps such as: presenting learning material, giving examples of questions and asking students work on the practice questions contained in the textbooks they use in teaching and then discuss them with students. Learning like this will not maximize the development of students' mathematical problem-solving skills. Students will only work on math problems based on what the teacher exemplifies. If they are given different problems they will experience difficulties in solving them.

According to Mayer (2004), guided discovery learning is a learning model that aims to train students to find concepts with the guidance of the teacher to avoid misconception. Students play an active role in the learning process by answering various questions or problems and solving problems to find a concept. In guided discovery learning, the teacher presents examples, guides to finding patterns in these examples, and provides conclusions when students have been able to describe ideas that have been taught by the teacher (Jacobsen, Eggen, \& Kauchak, 2009). As a studentcentered learning approach, the guided discovery approach supports students' problem-solving abilities (Markaban, 2006).

Learning media can also help students improve their understanding, present data interestingly, and reliably, facilitate data interpretation and condense information
(Arsyad, 2010). Learning media is a factor that supports the success of the learning process (Ahern, 2016). Through digital media and various types of educational technology can support students with a variety of learning abilities, providing more educational opportunities (Russell \& Hannon, 2012).

This research aims to answer the following questions. First, the research aims to analyze the characteristics of students, educator competence and curriculum analysis. Second is to design discovery learning based learning media that can improve problem-solving abilities.

This article has 4 sections. The first part explains the introduction, the second part presents the research method, the third part describes the results of the research and discussion, the fourth part is the conclusion and its implications.

\section{Method}

This research uses methods design research type Development Studies. Research Design is a development model for designing and developing an intervention in learning such as; teaching programs, strategies and learning materials (Plomp, 2013). The purpose of intervention in design research is to produce program designs, learning strategies, teaching materials, which can be used to solve problems in the process of learning or education empirically (Prahmana, 2017). Development Studies is the activity of developing design principles for the practical benefit of the field (Prahmana, 2017). This study consists of three stages, namely analysis, design, and evaluation (Akker, McKenney, \& Nieveen, 2006).

\section{Analysis Stage}

This stage is the initial stage of the research. The analysis carried out is the analysis of research subjects, curriculum analysis, and content analysis. The results of the 
analysis stage will be used as the basis for the next stage, namely designing products.

\section{Design Stage}

At this stage, the researcher designs the product to develop, namely the mathematics learning media according to the Guided Dis- covery. The design of teaching materials and learning media focuses on three things, namely content/content, constructs, and language that will be validated by experts. The prototype focus is explained as Table 1 .

Table 1. Focus prototype in

\begin{tabular}{|c|c|}
\hline Content & $\begin{array}{l}\text { - Media accordance with KI, KD, and GPA in the } 2013 \text { curriculum } \\
\text { - A context in accordance with the material and characteristics of } \\
\text { Guided Discovery } \\
\text { - Steps in the media are easy to operate. }\end{array}$ \\
\hline Construction & $\begin{array}{l}\text { Media complies with supporting theories with criteria: } \\
\text { - Developing problem-solving skills } \\
\text { - } \quad \text { Rich with the concept of } \\
\text { - Inviting further concept development. }\end{array}$ \\
\hline Language & $\begin{array}{ll}\text { - } & \text { Compatibility with Enhanced Spelling (EYD) } \\
\text { - } & \text { Easy to understand } \\
\text { - } & \text { Effective use of sentences }\end{array}$ \\
\hline
\end{tabular}

\section{Evaluation Stage}

The evaluation stage in this study uses the stages of formative evaluation developed by Tessmer (1993). The design flow of the evaluation phase in brief is as Figure 1.

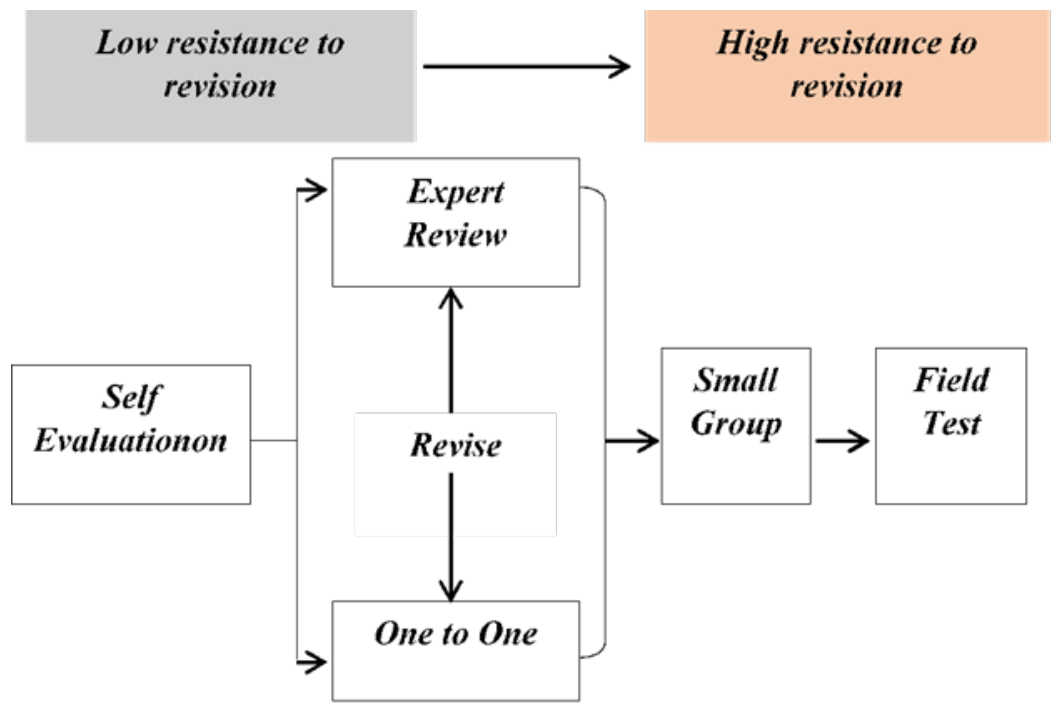

Figure 1. Design flow of the evaluation

Self-evaluation, At this stage researchers evaluate the learning media themselves if they are in accordance with the criteria in terms of content, construct, and language. The results of this stage are then called prototypes I.

Expert Review, At this stage the prototype I is tested by media experts. Experts will validate the contents, constructs, and language appropriately, in accordance with the principles and characteristics of the Guided Discovery. The focus of validation is the clarity of the content, the meaning of the picture, the suitability of the context used, and the language used. Expert test results will be used as a basis for revising prototype I. The results of prototype 1 revisions at this stage are called prototypes II. 
One-to-One, this prototype I stage is tested on the teacher and students separately between the teacher, students, and other students. This stage is carried out in parallel with the stage expert review, so the results of this stage are also used to revise prototype I to produce prototype II.

Small Group, This stage is the stage to test prototype II in a small group consisting of several students. The group of students has the same characteristics as the large group for the field test. This aims to determine the level of practicality of the Learning Media that has been designed. Furthermore, the results of the test were analyzed and the results were used as the basis for the prototype II revision. The results of the revision are referred to as prototype III.

Field Test, This stage is a testing stage of prototype III which has been valid and practical. This test is to see the potential effects of prototype III.

\section{Result and Discussion}

This research has been carried out in the analysis, design, and evaluation, stage but in the evaluation phase only were conducted self-evaluation and expert review. The stages that have been carried out are as follows:

\section{a. Analysis Stage}

This stage the researcher carried out several analyzes namely student analysis, educator competence, and curriculum analysis. The data was taken using a questionnaire with 100 students who were randomly selected at the Sunan Averroes Middle School and MTs Assalafiyyah Mlangi Yogyakarta.

Characteristics of students, questionnaire results showed that only $35 \%$ of students felt happy in the learning process, while $65 \%$ of students answered the learning process was not interesting. The learning process was monotonous and no learning innovation was stated by $85 \%$ of students. The use of learning media was rarely used, and learning took place in one direction.

Table 2. Percentage of Questionnaire Results Students

\begin{tabular}{lc}
\hline \multicolumn{1}{c}{ Statement of } & Percentage \\
\hline Fun learning process & $35 \%$ \\
The less interesting learning process & $65 \%$ \\
The use of learning media was rarely used & $85 \%$ \\
Learning occured in one direction. & $85 \%$ \\
\hline
\end{tabular}

Educator Competence Based on the results of interviews with educators in the field, it is known that the learning method of mathematics educators was still monotonous with the lecture method and written assignments. In accordance with the results of the student questionnaire which showed $85 \%$ of educators stated in the learning process initially interesting, but when the learning process continued in the following weeks the students became bored. $80 \%$ of educators stated that the performance and participation of students in learning decreased in the following week and were not interested and not passionate.

Curriculum The aspects in the 2013 Curriculum had not been implemented. Likewise between the principles, concepts, and facts in learning had not been implemented. It is reflected in the answers of students $(85 \%)$ that even if there was using learning media but still in one direction, so the participation of students in learning was still lacking. (95\%) students stated that when in the field they had difficulty applying concepts that were known by the facts.

\section{b. Design Stage}

The initial design is the first draft design which is still a prototype. It will then be validated by experts. The designed Mathematical learning media is as follows.

The Main Section, There are six selection buttons namely home, competency stan- 
dards, material, evaluation, profile, and exit. When a user selects the home button, instructions for using learning media appear. When a user selects the standard competency button, basic competency and competency standards will appear. When a user selects the material button, it will bring up the mate- rial section. When a user selects the evaluation button, the evaluation section will appear. When a user selects the profile button, the profile of the learning media maker (researcher) will appear. The exit button is used when a user wants to end learning media

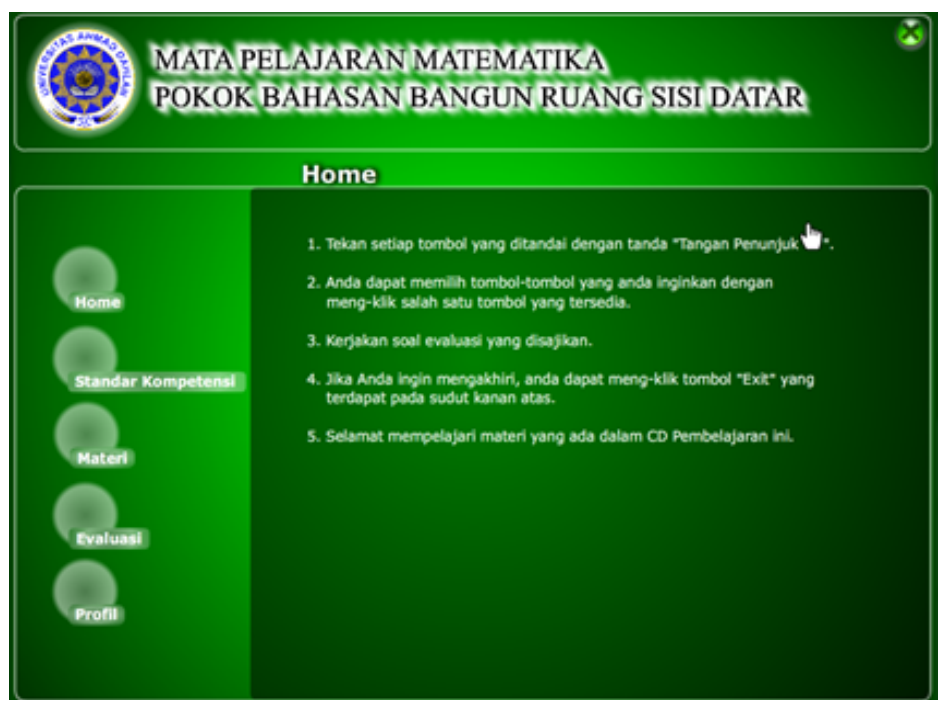

Figure 2. Main Section

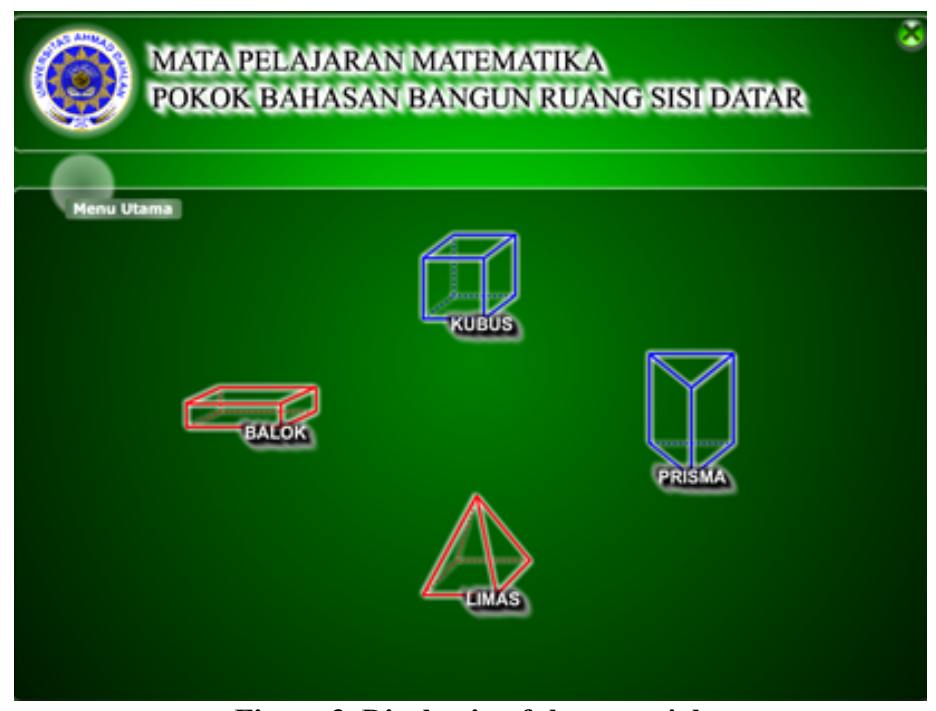

Figure 3. Display in of the material 


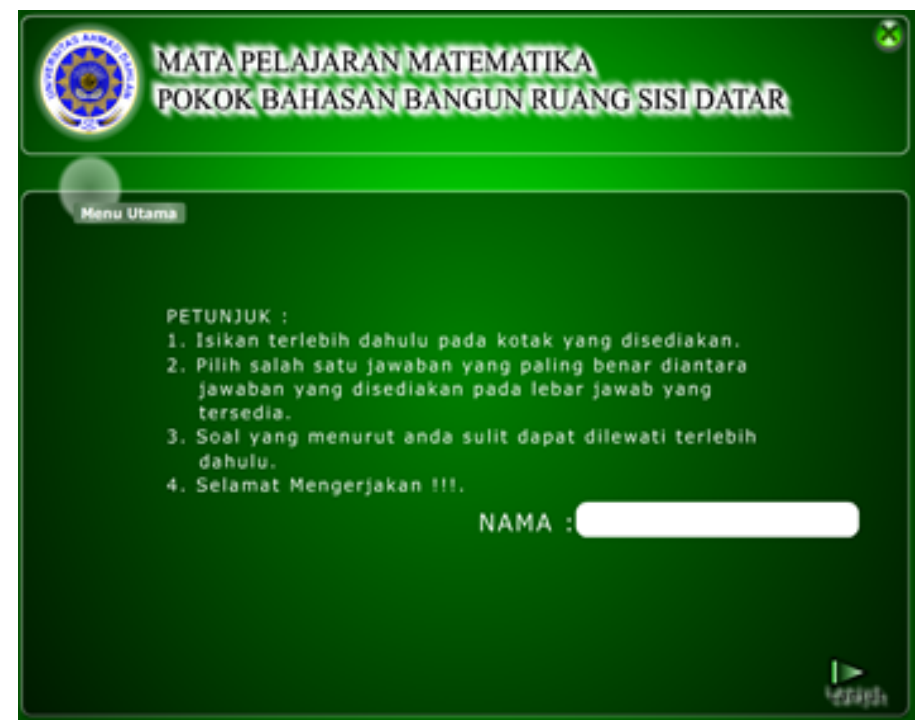

Figure 4. The initial display of evaluation

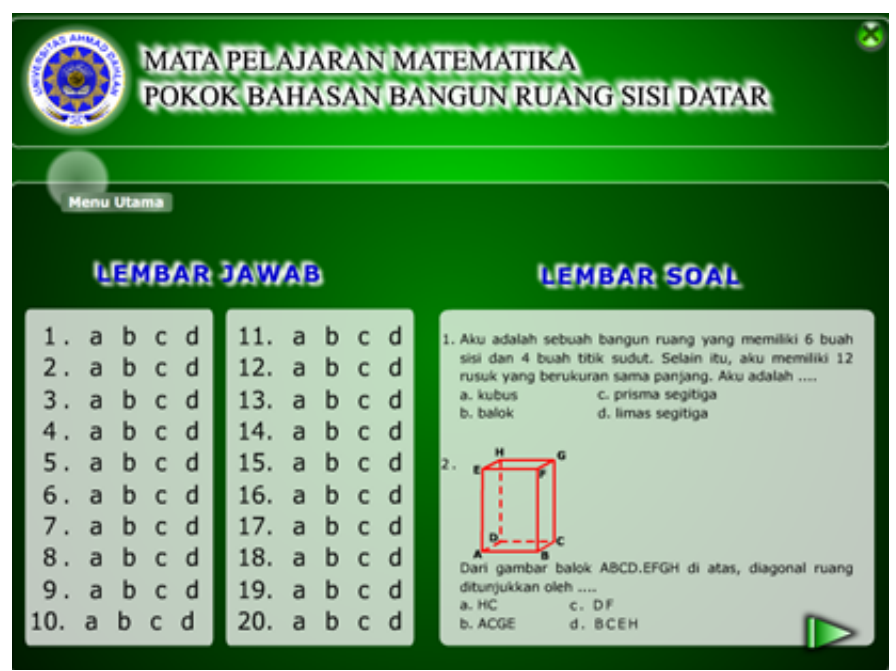

Figure 5. Display the answer sheets and about the

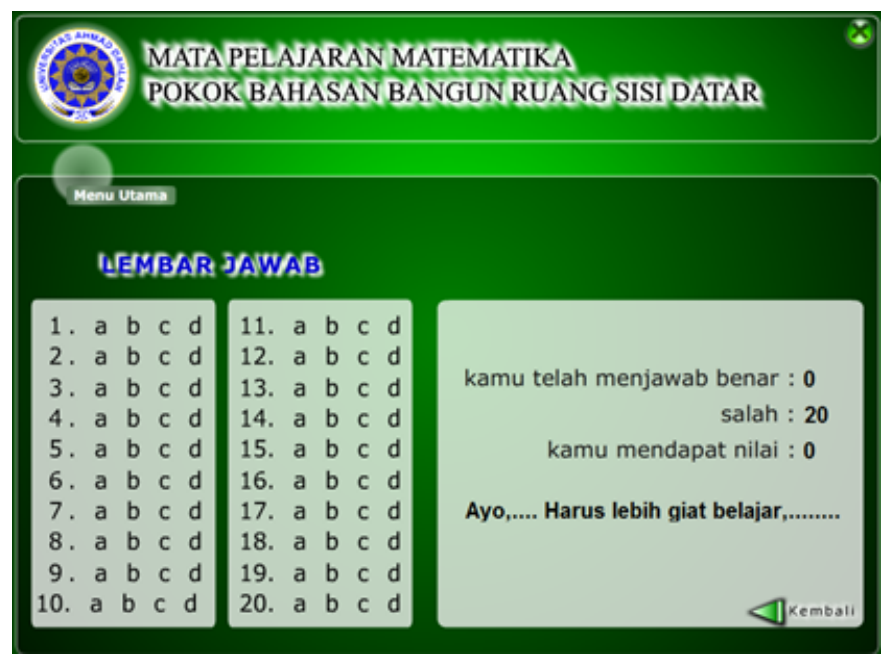

Figure 6. Display of results or value

Menu material, this section displays the the user selects the desired material, the seselection of material buttons consisting of lected material will appear. cubes, beams, prisms, and pyramid. When 
Evaluation section. The evaluation section will appear when a user selects the evaluation button on the main part. This evaluation section contains questions, computer answer sheets, and the value of the work on the questions. When a user selects the evaluation button available in the main section, it will immediately display the evaluation instructions, and in this section, a user is asked to fill in the full name in the place provided.

Question sheet and answer sheet, After a user fills in the name and then presses the start button on the bottom right then a question sheet will appear that contains questions to be answered by a user and the answer sheet. A user can choose the answers according to the correct user by selecting options on the answer sheet.

Results or The Value, After user finish answering the questions, a user will know the number of questions answered correctly, incorrectly answered and will know the value obtained.

\section{Evaluation Stage}

The evaluation stage use the stages of formative evaluation developed by Tessmer (1993), namely self-evaluation, expert review, one-to-one, small group and field test.
However, only carried out self-evaluation and expert review were carried out in the evaluation stage here.

Self Evaluation At this stage, researchers evaluate the media they have designed themselves. Researchers re-evaluate in terms of content, constructs, and language, as well as the writing system used in the media. There were several sentences on the media which were repaired and changed. The revised media is then called the prototype I.

Expert Review At this stage, researchers validate the learning media and assess the feasibility of the learning media to media experts and material experts. Media experts consist of two people, namely Mursid Wahyu Hananto and Syariful Fahmi. They are lecturers in the mathematics multimedia education course, FKIP, UAD. The material experts consists of 2 people, namely Pramudiastuti and Triyatmo. They are teachers of mathematics subjects at Baturetno State Junior High School 2. After receiving input from material experts and media experts, the learning media was revised to get prototype II. follows:

Table 3. Media Expert Comments or Suggestions and Revisions Conducted

\begin{tabular}{ll}
\hline \multicolumn{1}{c}{ Comments or Suggestions for } & \multicolumn{1}{c}{ Revisions } \\
\hline $\begin{array}{l}\text { Made by Letters in the initial display were too } \\
\text { fast, should be slowed down. }\end{array}$ & $\begin{array}{l}\text { Followed up according to input, because it was } \\
\text { necessary to improve the appearance of the } \\
\text { intro. }\end{array}$ \\
$\begin{array}{l}\text { The voice needed adjustment and voice control } \\
\text { because students had the right to choose to } \\
\text { listen or setup the volume of music. }\end{array}$ & $\begin{array}{l}\text { Follow up according to input because music } \\
\text { could support the learning atmosphere and } \\
\text { students had the right to control the voice. }\end{array}$ \\
$\begin{array}{l}\text { The initial material was associated with the } \\
\text { example of building space that was comparable } \\
\text { with the objects in the real world. }\end{array}$ & $\begin{array}{l}\text { Followed up in accordance with the input be- } \\
\text { cause to facilitate the understanding of the } \\
\text { material by students. }\end{array}$ \\
$\begin{array}{l}\text { Animation on the material of the volume of } \\
\text { cubes, beams, and limas needed enhancement.. }\end{array}$ & $\begin{array}{l}\text { Followed up according to input because good } \\
\text { animation could facilitate students in unders- } \\
\text { tanding the material. }\end{array}$ \\
$\begin{array}{l}\text { The clicking word was replaced by pressing. } \\
\text { Followed up according to the input because it } \\
\text { would make easier to understand. }\end{array}$ \\
$\begin{array}{l}\text { The conclusions of the material were clarified } \\
\text { with different boxes or colors. }\end{array}$ & $\begin{array}{l}\text { Followed according to input because it needed } \\
\text { to reinforce conclusions and facilitate students } \\
\text { in remembering. }\end{array}$ \\
\hline
\end{tabular}




\section{Conclusion}

Based on the preliminary analysis (covering an analysis of student characteristics, educator competence, and curriculum analysis), learning media to support learning following the 2013 curriculum needs to be developed.

This study has successfully designed mathematics learning media according to discovery learning. Mathematics learning media has been evaluated in the stages of self-evaluation and expert review..

\section{References}

Ahern, T. C. (2016). A Waterfall Design Strategy for Using Social Media for Instruction. Journal of Educational Technology Systems, 44(3), 332-345.

Akker, J. Van den, McKenney, S., \& Nieveen, N. (2006). Design research from a curriculum perspective. In J. Van den Akker, K. Gravemeijer, S. McKenney, \& N. Nieveen (Eds.), Educational Design Research (pp. 6790). London: Routledge.

Arsyad, A. (2010). Media Pembelajaran. Jakarta: Rajawali Pers.

Bell, F. H. (1978). Teaching and Learning Mathematics. USA: Wm.C. Brown Company Publishers.

Branca, N. A. (1980). Problem Solving as A Goal, Proccess and Basic Skill. In S. Krulik \& R. E. Reys (Eds.), Problem Solving in School Mathematic. Virginia: NCTM Inc.

Depdiknas. (2006). Peraturan Mendiknas No 22 Tahun 2006 Standar Isi (Regulation of Minister of National Education No. 22 year 2006 of content standard). Jakarta: Depdiknas.

Jacobsen, D. A., Eggen, P., \& Kauchak, D. (2009). Methods For Teaching : Metode-metode Pengajaran Meningkatkan belajar siswa TK-SMA. Yogyakarta: Pustaka Pelajar.

Kirkley, J. (2003). Principles for Teaching Problem Solving. Technilca Paper no 4, Plato Learning Inc.

Markaban. (2006). Model Pembelajaran
Matematika dengan Pendekatan Penemuan Terbimbing. Yogyakarta: PPPG Matematika.

Mayer, R. E. (2004). Should there be a threestrikes rule against pure discovery learning? American Psychologist, 59(1), $14-19$.

Mulyati, T. (2016). Kemampuan pemecahan masalah matematis siswa sekolah dasar (mathematical problem solving ability of elementary school students). EDUHUMANIORA: Jurnal Pendidikan Dasar, 3(2), 1-20.

National Council of Teachers of Mathematics. (2000). Principles and Standards for School Mathematics. Reston. VA: NCTM.

Plomp, T. (2013). Educational Design Reasearch: An Introduction. In T. Plomp \& N. Nieveen (Eds.), Educational Design Research Part A: An Introduction (pp. 10-51). Eschede: Netherlands Institute for Curriculum Development (SLO).

Polya, G. (1973). How to Solve It: A New Aspect of Mathematical Method. The Mathematical Gazette (Vol. 30). Princeton, New Jersey: Princeton University Pers. https://doi.org/10.2307/3609122

Prahmana, R. C. I. (2017). Design Research (Teori dan Implementasinya: Suatu Pengantar). Depok: Rajawali Pers.

Ruseffendi, E. T. (2006). Pengantar kepada membantu guru mengembangkan kompetensinya dalam pengajaran matematika untuk meningkatkan CBSA (edisi revisi). Bandung: Tarsito.

Russell, A., \& Hannon, D. (2012). A cognitive load approach to learnercentered design of digital instructional media and supporting accessibility tools. In Proceedings of the Human Factors and Ergonomics Society Annual Meeting (pp. 556-560). Los Angeles: SAGE Publications.

Santosa, C. A. H. F., Prabawanto, S., \& Marethi, I. (2019). Fostering Germane Load Through Self-Explanation Prompting In Calculus Instruction. 
IJOLAE: Indonesian Journal on

$37-46$.

Learning and Advanced Education, 1(1), 